\title{
Organiziranost služb Državnega zbora Republike Slovenije - izkušnje in novim izzivom naproti
}

\author{
UDK: $342.5(497.4)$ \\ Lovro Lončar \\ lovro.loncar@gmail.com
}

\begin{abstract}
IZVLEČEK
Službe Državnega zbora Republike Slovenije opravljajo strokovna, administrativna in druga opravila ter tehnične naloge, s katerimi se zagotavljajo pogoji za delo Državnega zbora Republike Slovenije. Državni zbor Republike Slovenije pa je najvišje zakonodajno in predstavniško telo v Sloveniji. Zato je poslanstvo služb še posebej pomembno in odgovorno, čeprav mnogokrat v javnosti neopazno, vendar brez podpore služb poslanke in poslanci ne bi imeli ustreznih in kakovostnih pogojev za svoje delo. Pomembno je, da se službe pri svojem delu prilagajajo razvoju sodobnega poslovanja $v$ javni upravi, hkrati pa zagotavljajo tradicionalno funkcijo in položaj, ki jo službe v parlamentih $z$ dolgoletno evropsko parlamentarno demokracijo imajo - to pa je strokovnost, usposobljenost in predvsem politična neodvisnost. Pred službami Državnega zbora Republike Slovenije je v prihodnjih letih za zagotavljanje teh ciljev na še višjem nivoju kar nekaj izzivov, zadnja velika izkušnja pa je bilo predsedovanje Slovenije Svetu EU na parlamentarni ravni.
\end{abstract}

Ključne besede: državni zbor, službe, uslužbenci, organizacija, menedžment, javna uprava.

\section{Uvod}

Z reformo slovenske javne uprave $v$ preteklih letih so bila na novo postavljena izhodišča za delovanje javne uprave in s tem tudi menedžmenta $v$ javni upravi - t.i. upravnega menedžmenta. Za opravljanje nalog upravnega menedžerja pa je splošno značilno, da se mora na spremembe pravočasno pripraviti, za kar je pogoj, da je menedžer za opravljanje svojega dela ustrezno usposobljen in izobražen. Vzpostavljen mora biti sistem odgovornosti, cilji, ki jih želi doseči, morajo biti jasni. Le menedžer, ki je popolnoma seznanjen s projektom sprememb in ki v projekt zaupa, lahko motivacijsko deluje na svoje podrejene, predvsem pa jih mora o morebitnih novostih pravočasno in temeljito seznaniti. 
Lovro Lončar

Organiziranost služb Državnega zbora Republike Slovenije izkušnje in novim izzivom naproti

Upravni menedžment v Državnem zboru Republike Slovenije ( $v$ nadaljevanju: državni zbor) ima nalogo organizacije in vodenja strokovnih služb državnega zbora, ki posredno iz "ozadja « skrbijo za to, da zakonodajni postopek kot glavni proces $v$ državnem zboru nemoteno poteka. Upravni menedžment oz. službe se neposredno ne spuščajo $v$ vsebino odločitev poslank in poslancev, torej so izločeni iz politike, ki ima v državnem zboru kot »hiši demokracije» drugače seveda glavno besedo.

Državni zbor opravlja zahtevno in odgovorno delo. Zato morajo biti vsi organizacijski ukrepi, povezani z njim, premišljeni, da ne povzročijo zastojev $v$ delovanju državnega zbora. Za to pa so odgovorni vsi t. i. najvišji upravni menedžerji, zaposleni v službah državnega zbora. Organiziranje in vodenje služb sta kot najpomembnejša vidika menedžmenta stalna procesa, zato ju je treba stalno nadzorovati in dopolnjevati, da se zagotovi izvajanje temeljnih načel sodobne uprave: zakonitost, objektivnost, strokovnost, politična nevtralnost, usmerjenost k uporabniku, odprtost, transparentnost, uspešnost, učinkovitost in ekonomičnost. Pravne podlage, ki so na novo opredelile položaj javnih uslužbencev (Zakon o javnih uslužbencih, Ur. list RS, št. 32/06- prečiščeno besedilo, št. 33/07, 63/07, 65/08, 69/08; Zakon o sistemu plač v javnem sektorju, Ur. list RS, št. 14/06 - uradno prečiščeno besedilo, št. 57/07, 95/07,110/07,17/08, 58/08, 69/08, 69/08, 80/08; drugi predpisi), naj bi omogočale najvišjim upravnim menedžerjem izvajanje projektov in drugih nalog $v$ skladu s predpisi na nov, sodobnejši način, delno primerljiv tudi $s$ tistim $\vee$ gospodarstvu, seveda ob omejitvah, ki so značilne za delovanje javne uprave. Menedžerji $v$ javni upravi pridobivajo na pomenu, saj je dober menedžment oz. menedžer ključen porok za kakovostno izvedbo upravnih in drugih nalog $\vee$ upravi. $\vee$ prispevku naprej predstavljamo poslanstvo ter ustavne pristojnosti in organizacijo državnega zbora na splošno, $\checkmark$ nadaljevanju organiziranost služb državnega zbora in njihove pristojnosti oz. naloge in značilnosti, prispevek pa zaključujemo s predstavitvijo ključnih izzivov oz. nalog, ki so pred službami državnega zbora v prihodnje. Osnovni namen prispevka je torej predstavitev služb državnega zbora in njihovih ključnih nalog oz. izzivov v prihodnje.

\section{Splošno o državnem zboru}

Državni zbor je najvišje predstavniško in zakonodajno telo. Sestavlja ga 90 poslank in poslancev, ki so izvoljeni za štiriletni mandat na neposrednih 
demokratičnih volitvah (80. člen Ustave Republike Slovenije, Ur. list RS, št. 33/91, 42/97, 66/00, 23/03, 69/04, 68/06) - (v nadaljevanju: ustava). Pravice in dolžnosti poslank in poslancev opredeljuje Zakon o poslancih (Ur. list RS, št. 24/05 - uradno prečiščeno besedilo). Poslanke in poslanci obravnavajo in sprejemajo zakone in druge akte ter opravljajo nadzorno in volilno funkcijo. Svojo funkcijo opravljajo $v$ različnih delovnih telesih državnega zbora.

Slika 1: Pravice poslancev (vir: Državni zbor, 2008)

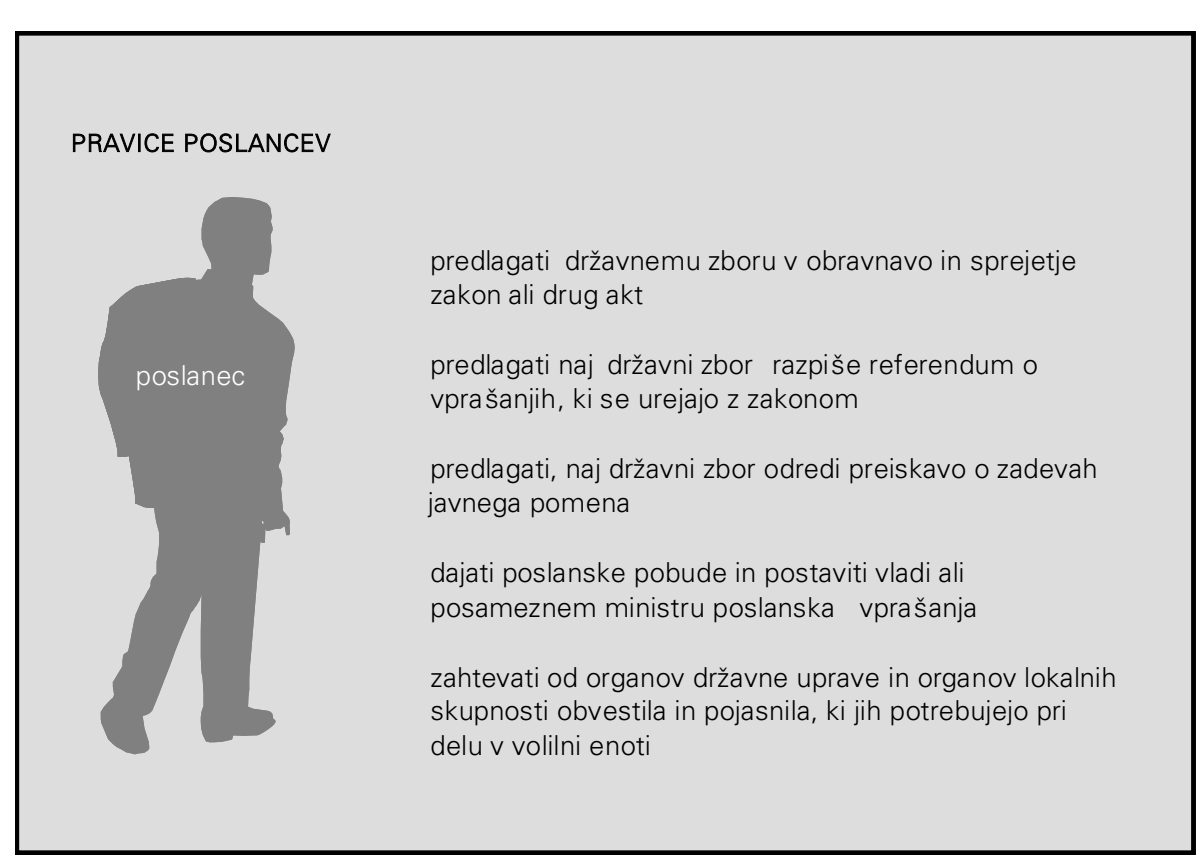

$\checkmark$ državnem zboru delujejo torej na eni strani funkcionarji - politiki (neposredno izvoljeni poslanke in poslanci) s svojimi najožjimi sodelavkami in sodelavci kot javnimi uslužbenci, zaposlenimi $v$ službah poslanskih skupin za določen čas trajanja mandata poslanske skupine, na drugi strani pa javni uslužbenci v strokovnih službah državnega zbora. Obe skupini uslužbencev sta za delo poslank in poslancev izjemno pomembni, pa čeprav sta javnosti mnogokrat skriti in neopazni.

Struktura organiziranosti služb državnega zbora je primerljiva s strukturo služb $\vee$ nekaterih drugih evropskih parlamentih, po organiziranosti katerih se je zgledovalo tudi vodstvo državnega zbora pri predlogu in sprejemu zadnjih sprememb organiziranosti služb državnega zbora (t. i. skandinavski model organiziranosti parlamentarnih služb). 
Lovro Lončar

Organiziranost služb Državnega zbora Republike Slovenije izkušnje in novim izzivom naproti

\section{Organizacija in naloge služb državnega zbora}

Za podporo nemotenemu delu poslank in poslancev skrbijo službe državnega zbora, ki opravljajo strokovna, administrativna in druga opravila ter tehnične naloge, s katerimi se zagotavljajo pogoji za delo državnega zbora. Njihovo organiziranost in strukturo opredeljuje Odlok o notranji organizaciji, delovnih mestih in nazivih v službah DZ (Ur.list RS, št. 50/04,32/08)- ( $v$ nadaljevanju: Odlok).

Službe državnega zbora vodi generalni sekretar državnega zbora, ki je poleg poslank in poslancev $v$ državnem zboru po statusu edini funkcionar lahko bi ga imenovali tudi "upravni funkcionar", saj opravlja strokovne in ne politične naloge. Imenuje ga državni zbor za mandatno obdobje državnega zbora in je predstojnik služb državnega zbora. Generalni sekretar državnega zbora organizira, usklajuje delo služb pri opravljanju del in nalog za državni zbor, njegova delovna telesa, poslanske skupine in poslance, zagotavlja enotno delovanje služb, skrbi za razvoj organizacije in dela ter opravlja druga dela in naloge $v$ skladu s Poslovnikom Državnega zbora (Ur.list RS št.35/02, 60/04, 64/07, 92/07 ) - (v nadaljevanju: poslovnik) in v skladu z drugimi predpisi. Skupaj z vodji posameznih služb torej skrbi za planiranje, organiziranje, usklajevanje in nadziranje ter razvoj služb državnega zbora, ki skrbijo za opravljanje strokovnih, administrativnih in drugih opravil ter tehničnih nalog $v$ državnem zboru.

Po veljavni sistemizaciji delovnih mest (Pravilnik o notranji organizaciji in sistemizaciji delovnih mest v službah DZ, št. 040-03/89-1/56 z dne 01.07.2004, 25.11.2004, 28.01.2005, 11.04.2005, 01.04.2006, 15.11.2006, 09.03.2007, 06.06.2007, 15.01.2008, 23. 01. 2008, 29.07.2008) - ( $v$ nadaljevanju: pravilnik) je trenutno 358 sistemiziranih delovnih mest $v$ državnem zboru ( trenutno zasedenih 325 mest), od tega 30 mest uradnikov na položaju, 159 uradniških mest in 169 strokovnotehničnih delovnih mest. Trenutno je od vsega števila zaposlenih $v$ državnem zboru $72 \%$ žensk in 28\% moških, povprečna starost zaposlenih je 42,3 let ( vir: Državni zbor RS: Kadrovsko poročilo DZ za obdobje 2004-2008, Oddelek za organizacijo in kadre, Ljubljana, oktober 2008).

Glede na razvejanost služb je vloga t. i. upravnega menedžementa služb državnega zbora še posebej pomembna. Ključni nalogi upravnega menedžmenta v državnem zboru sta zagotoviti nemoten in zakonit potek t. i. zakonodajnega postopka ter $\vee$ povezavi s tem zagotoviti nemoteno delovanje in razvoj služb državnega zbora. 


\section{Organiziranost služb Državnega zbora Republike Slovenije -} izkušnje in novim izzivom naproti

Brez medsebojne povezanosti obeh nalog ne gre. Pri koordinaciji vseh služb je treba zagotavljati ustavnost in zakonitost dela, istočasno pa tudi javnost dela državnega zbora.

Vodstvo državnega zbora mora zagotavljati stalno fleksibilnost služb državnega zbora, tako organizacijsko kot kadrovsko in vsebinsko glede na pristojnosti in naloge služb. Službe se morajo pri svoji organizaciji dela včasih prilagajati tudi sprejetim političnim odločitvam. Če je npr. sprejeta odločitev o ustanovitvi novega delovnega telesa v državnem zboru, so službe dolžne le-temu zagotoviti vso strokovno pomoč ( sistemizacija, nove zaposlitve, prostori, drugi materialni pogoji, itd.). Zatorej je stalno prilagajanje sistemizacije državnega zbora ob upoštevanju zakonskih omejitev normalen in stalen pojav ob tem, da se vedno najprej iščejo notranje kadrovske rešitve - prerazporeditve. Kadrovska funkcija državnega zbora mora torej stremeti za čim večjo interdisciplinarnostjo kadrov, da lahko zagotovi ustrezno in učinkovito kadrovsko podporo.

Avtonomija in samostojnost državnega zbora kot zakonodajne veje oblasti se kaže tudi $v$ strukturi lastnih služb, seveda ob pogojih racionalnosti in izkoriščenosti resursov, ki so mu pri tem na voljo, tako da službe s svojimi dejavnostmi zagotavljajo popolno in neodvisno podporo delovanju državnega zbora, od strokovnih, prevajalskih, informacijskih, gostinskih, tiskarskih, varnostnih, prevoznih, čistilnih, receptorskih, protokolarnih, knjižničnih, raziskovalnih, dokumentacijskih in drugih storitev. S tem zagotavljajo izvajanje vseh ključnih funkcij neke organizacije: tehnično, finančno-računovodsko, varnostno, administrativno in tudi strokovno svetovalno ter drugo.

Koncept dela in organizacije služb državnega zbora določa torej Odlok. Leta zagotavlja pregledno in dokaj učinkovito organizacijo ter notranjo strukturo služb.

Službe Državnega zbora in njihove naloge glede na organigram v skladu z Odlokom torej so (vir: spletna stran Državnega zbora Republike Slovenije: http://www.dz-rs.si/index.php?id=89):

Kabinet predsednika državnega zbora opravlja strokovne, svetovalne, organizacijske in administrativno-tehnične naloge, vezane na funkcije predsednika in podpredsednikov državnega zbora.

Zakonodajno-pravna služba daje mnenja o skladnosti predlogov zakonov, drugih aktov in amandmajev z ustavo in pravnim sistemom ter o zakonodajnotehničnih vidikih predlogov; pripravlja strokovne podlage za oblikovanje mnenj 
Lovro Lončar

Organiziranost služb Državnega zbora Republike Slovenije izkušnje in novim izzivom naproti

oziroma odgovorov državnega zbora Ustavnemu sodišču Republike Slovenije v postopkih za oceno ustavnosti in zakonitosti aktov; pripravlja mnenja glede drugih zadev $v$ skladu s poslovnikom; daje mnenja predsedniku državnega zbora in pojasnila poslancem glede vprašanj pravne narave; pripravlja uradna prečiščena besedila zakonov in opravlja redakcijo besedil zakonov in drugih aktov, ki jih sprejme državni zbor, za objavo $\vee$ Uradnem listu Republike Slovenije.

Urad generalnega sekretarja opravlja strokovna in administrativna dela za generalnega sekretarja ter naloge na področju notranje revizije in varovanja državnega zbora.

Služba za odnose z javnostmi obvešča javnost o delu državnega zbora in njegovih delovnih teles, o mednarodni in drugih dejavnostih; zagotavlja pogoje predstavnikom medijev za njihovo delo $v$ državnem zboru, izdaja glasilo državnega zbora ter druge publikacije in izvaja druge oblike komuniciranja z različnimi javnostmi.

Sekretariat državnega zbora opravlja strokovne in administrativne naloge na področju priprave in poteka sej državnega zbora in njegovih delovnih teles, mednarodne dejavnosti in protokola ter raziskovalno-dokumentacijske dejavnost in sicer $v$ dveh sektorjih.

Sektor za izvajanje dejavnosti državnega zbora, ki ga sestavljata Oddelek za pripravo in izvedbo sej državnega zbora in delovnih teles ter Oddelek za mednarodno dejavnost, protokol in prevajanje.

Oddelek za pripravo in izvedbo sej državnega zbora in delovnih teles proučuje problematiko in predloge zakonov, drugih aktov ter zadeve Evropske unije; daje strokovna mnenja in stališča; pripravlja poročila, sklepe, analize in informacije ter druga gradiva; pripravlja strokovne podlage za oblikovanje mnenj oziroma odgovorov državnega zbora Ustavnemu sodišču Republike Slovenije v postopkih za oceno ustavnosti in zakonitosti aktov; pripravlja strokovne podlage za odločitev državnega zbora $v$ zvezi $z$ avtentično razlago zakonov in drugih aktov državnega zbora; oblikuje strokovne podlage $v$ zvezi z oblikovanjem politike na določenem področju in spremlja njeno izvajanje ter daje pojasnila poslancem glede vprašanj poslovniške narave.

Uradniki pri mandatno-volilni komisiji poleg nalog za komisijo urejajo tudi statusne in kadrovske zadeve za poslance in druge funkcionarje; vodijo kadrovsko evidenco le-teh in skrbijo za zagotavljanje materialnih pogojev dela za poslance. Uradniki pri komisiji za peticije ter za človekove pravice in enake možnosti poleg nalog za komisijo obravnavajo in opravljajo strokovne zadeve $v$ 


\section{Organiziranost služb Državnega zbora Republike Slovenije -} izkušnje in novim izzivom naproti

zvezi s peticijami, vlogami in pritožbami naslovljenimi ali odstopljenimi državnemu zboru.

Oddelek za mednarodno dejavnost, protokol in prevajanje, ki opravlja naloge s področja mednarodne dejavnosti; izvaja strokovno pomoč delegacijam $\checkmark$ mednarodnih organizacijah; organizira in izvaja protokolarne dejavnosti; opravlja naloge prevajanja in redakcije prevodov ter simultano in konsekutivno prevajanje iz tujih jezikov v slovenščino in obratno.

Raziskovalno-dokumentacijski sektor zagotavlja raznovrstne in politično nepristranske podatke in informacije, s čimer zadošča informacijskim potrebam, ki nastajajo pri izvajanju temeljnih nalog in ciljev državnega zbora, kot jih določajo ustava, poslovnik, zakoni in drugi akti. $S$ tem posredno prispeva $k$ boljšemu in učinkovitejšemu izvajanju funkcij državnega zbora ter $k$ njegovi večji odprtosti in preglednosti delovanja.

Raziskovalni oddelek pripravlja raziskovalne naloge z različnih strokovnih področij; strokovne analize o vprašanjih, ki se nanašajo na delo državnega zbora, njegovih delovnih teles in služb državnega zbora, predvsem pa primerjalne preglede $v$ zvezi $s$ posameznimi zakonskimi rešitvami, poslovniškimi določbami, položajem poslancev, delovanjem parlamentov in podobno. Pripravlja tudi poročila o delu državnega zbora.

Dokumentacijsko-knjižnični oddelek opravlja naloge specialne knjižnice specializiranega informacijskega centra, s pomočjo katerega notranji uporabniki (vodstvo državnega zbora, poslanske skupine, poslanke in poslanci ter njihove sodelavke in sodelavci) pridobivajo raznovrstne informacije, ki jih potrebujejo ob zakonodajnem postopku oziroma drugih nalogah. Zunanjim uporabnikom pa zagotavlja tiste informacije, ki so $v$ zvezi z zakonodajnim postopkom oziroma z drugim delom državnega zbora.

Opravlja tudi redakcijo dobesednih zapisov sej državnega zbora in lekturo uradnih dopisov ter jezikovno svetovanje.

\section{Direktorat}

Splošni sektor oblikuje sistemske rešitve in pripravlja navodila ter druge splošne akte služb državnega zbora, ki urejajo finančne, kadrovske in druge organizacijske zadeve. Splošni sektor sestavljata: Oddelek za organizacijo in kadre ter Finančno-računovodski oddelek.

Oddelek za organizacijo in kadre skrbi za organizacijo in razvoj služb: organizira in izvaja kadrovsko politiko (načrtovanje in razvoj kadrov, vodenje vseh kadrovskih seznamov ter uresničevanje pravic in obveznosti iz delovnega razmerja) 
Lovro Lončar

Organiziranost služb Državnega zbora Republike Slovenije izkušnje in novim izzivom naproti

ter načrtuje sistem izobraževanja javnih uslužbencev in poslancev. Oddelek organizira in spremlja izvajanje nalog s področja varnosti in zdravja pri delu ter zagotavlja izvajanje nalog $\vee$ zvezi z dodatno strokovno pomočjo poslancem.

Finančno-računovodski oddelek opravlja naloge $s$ finančnega in računovodskega področja; pripravlja izhodišča finančnega načrta in letnega poslovnega poročila.

Informacijski sektor pripravlja in izvaja razvojne programe s področja informacijske in avdio-video tehnologije, upravljanja dokumentov, izdelave magnetogramov ter razmnoževanja in tiskanja gradiv.

Oddelek za razvoj informacijskega sistema opravlja naloge s področja razvoja in vzdrževanja informacijskih sistemov in tehnologij, informacijske podpore zakonodajnemu postopku in drugim procesom ter avdio-video podpore sejam in dogodkom.

Oddelek za delo z gradivi in pošto sprejema, obdeluje, odpremlja vhodne in izhodne dokumente ter ureja dokumentarno in arhivsko gradivo.

Oddelek operaterski servis opravlja naloge pisanja, urejanja in objave magnetogramov sej državnega zbora in njegovih delovnih teles ter drugih dogodkov.

Oddelek tiskarna opravlja naloge razmnoževanja, tiskanja in grafične obdelave gradiv.

Operativno-tehnični sektor povezuje Oddelek za investicije in vzdrževanje, Oddelek za prevoze, Oddelek za gostinske storitve ter Oddelek za receptorska in telefonska dela.

Oddelek za investicije in vzdrževanje načrtuje, organizira in koordinira izvajanje tekočega investicijskega vzdrževanja, hišniških opravil, upravljanja ter obratovanja objektov in naprav; skrbi za izvajanje nalog s področja varstva pri delu in požarnega varstva; nabavlja osnovna sredstva, opremo, drobni inventar ter pisarniški in drug material; skrbi za čiščenje in urejanje prostorov.

Oddelek za gostinske storitve opravlja gostinske storitve $\vee$ restavraciji Državnega zbora, na sejah, sestankih in protokolarnih dogodkih.

Oddelek za prevoze organizira in izvaja avtomobilske prevoze za službene in protokolarne potrebe ter skrbi za vzdrževanje službenih vozil.

Oddelek za receptorska in telefonska dela sprejema in usmerja stranke in obiskovalce $\vee$ zgradbi državnega zbora, vodi njihovo evidenco ter posreduje telefonske zveze in klice. 
Službe poslanskih skupin zagotavljajo strokovno in administrativno pomoč poslancem. Proučujejo problematiko in predloge zakonov in drugih aktov ter zadeve Evropske unije; dajejo strokovna mnenja in stališča; pripravljajo poročila, sklepe, analize in informacije ter druga gradiv; oblikujejo strokovne podlage $v$ zvezi z oblikovanjem politike na določenem področju in spremljajo njeno izvajanje ter dajejo pojasnila poslancem glede vprašanj poslovniške narave.

\section{Slika 2: Organigram strukture služb Državnega zbora RS}

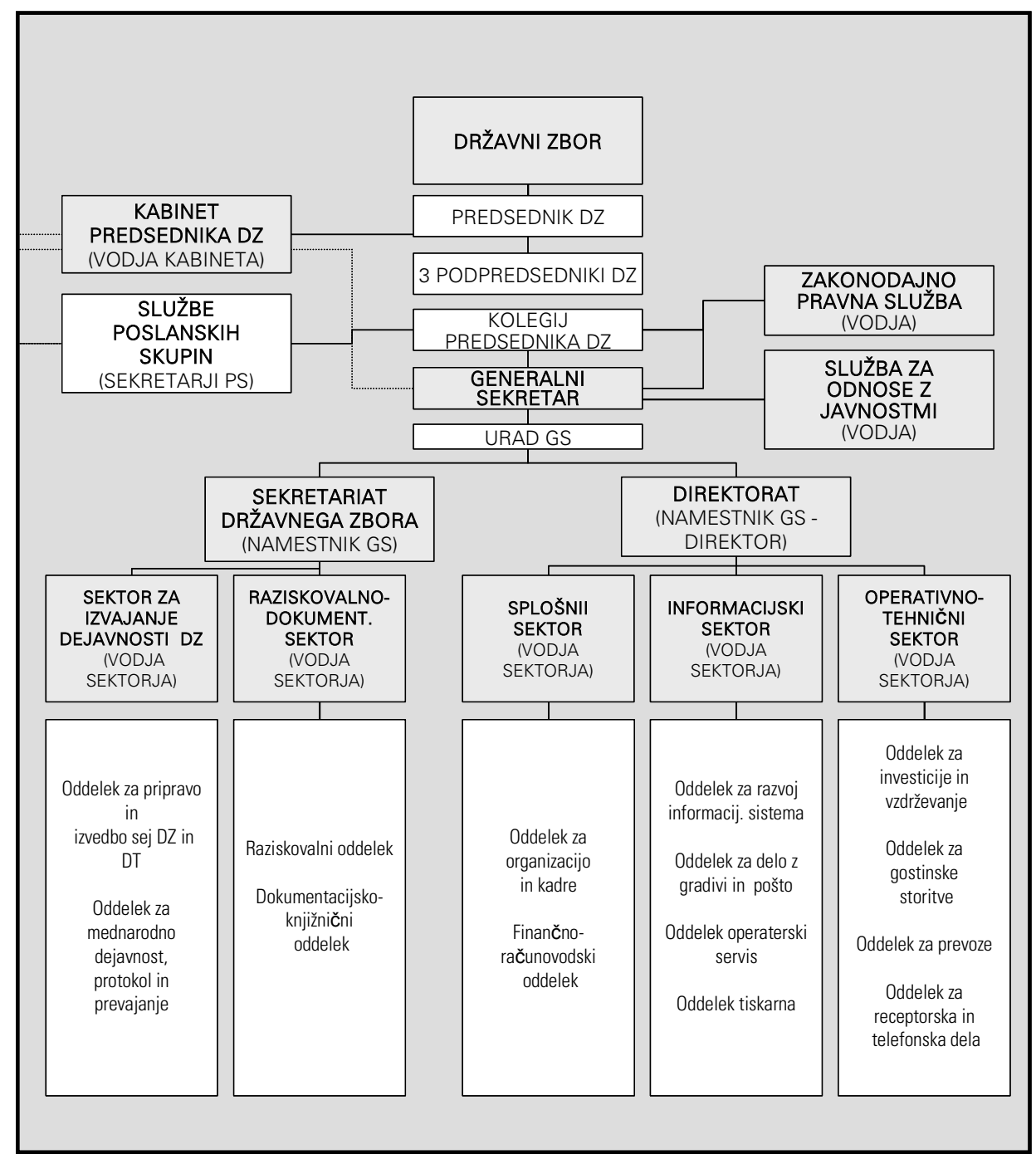

Vir: Državni zbor, 2008 
Lovro Lončar

Organiziranost služb Državnega zbora Republike Slovenije izkušnje in novim izzivom naproti

Vodje služb navedenih posameznih organizacijskih enot opravljajo naloge $v$ skladu s pristojnostmi služb, načrtujejo, organizirajo, usmerjajo, vodijo in nadzorujejo opravljanje dela $\vee$ notranjih organizacijskih enotah. Vodje služb do vključno nivoja vodje sektorjev državnega zbora sestavljajo kolegij generalnega sekretarja, ki je posvetovalno telo in kjer se obravnavajo vprašanja, ki so skupnega pomena za službe državnega zbora.

Državni zbor s svojimi službami torej zagotavlja čim boljše pogoje za delo in izvajanje nalog poslank in poslancev ter državnega zbora kot institucije. Pri tem se državni zbor srečuje s predvidljivimi in nepredvidljivimi aktivnostmi. Med prve sodijo redne aktivnosti državnega zbora (npr.: redne seje, načrtovana mednarodna dejavnost), med druge pa npr. izredne seje državnega zbora in druge aktivnosti, ki jih povzročijo morebitni nepredvideni dogodki in aktivnosti državnega zbora.

Za vodenje služb državnega zbora je izjemnega pomena koordinacija aktivnosti, usklajevanje nalog in hiter pretok informacij. To se uresničuje s sodobnimi komunikacijskimi sredstvi ter projektnim delom, ki zahteva poleg strokovnosti in izkušenj včasih tudi doseganje kompromisov na strokovnih in pravnih podlagah. Zato je tudi z ustreznimi notranjimi akti predpisano, da morajo za uspešno in smotrno izvrševanje nalog notranje organizacijske enote in posamezni javni uslužbenci med seboj sodelovati, tako da usklajujejo programe dela, izmenjujejo mnenja, izkušnje, podatke in obvestila ter sodelujejo $v$ delovnih skupinah (določeno $v$ pravilniku). Delovanje državnega zbora je še posebej vezano na roke, določene z različnimi predpisi (tudi ustavo), zato so službe dolžne zagotoviti ažurnost posredovanja podatkov in informacij za zagotovitev spoštovanja teh rokov pri obravnavi posameznih zadev. Tako kot $v$ gospodarstvu prepočasen odziv na tržne zahteve, ki lahko pomeni težave $\vee$ poslovanju in likvidnosti podjetja, je $\vee$ državnem zboru pomemben takojšen odziv na predloge zakonov in drugih aktov, posredovanih $v$ obravnavo, da ne pride zaradi morebitnega neupoštevanja ali zamude rokov npr. celo do neustavnih situacij, seveda pa to ni odvisno le od služb, ampak tudi od političnih odločitev poslank in poslancev. 


\section{Primer izkušnje organiziranosti služb državnega zbora $v$ času predsedovanja Slovenije Svetu EU}

Slovenija je v prvi polovici leta 2008 predsedovala Svetu EU in bila s tem prva nova članica EU, ki je imela to pomembno nalogo po širitvi EU leta 2004. Pri organizaciji dogodkov predsedovanja Svetu EU na parlamentarni ravni so službe državnega zbora pridobile izjemne izkušnje, ki so lahko pomembne za prihodnjo organiziranost in delovanje služb, ne samo ob tovrstnih dogodkih, ampak tudi stalno.

Državni zbor se je priprav na predsedovanje lotil takoj po sprejemu odločitve o sprejemu predsedovanja $\vee$ državnem zboru $\vee$ novembru 2004. Strateške odločitve $v$ zvezi z aktivnostmi državnega zbora $v$ obdobju priprav in predsedovanja Svetu EU (potrjevanje predlogov aktivnosti, vključitev delovnih teles, itd.) je sprejemal kolegij predsednika državnega zbora. Aktivnosti je vodil oziroma usklajeval predsednik državnega zbora $v$ sodelovanju z generalnim sekretarjem državnega zbora in projektno skupino za predsedovanje. Pri tem je bilo izredno pomembno, da je bil predhodno usklajen plan rednega dela državnega zbora, predsedovanja Svetu EU in drugih mednarodnih aktivnosti.

Generalni sekretar državnega zbora je v sodelovanju s projektno skupino kolegij predsednika državnega zbora redno seznanjal s potekom priprav na predsedovanje Svetu EU v državnem zboru.

Državni zbor je moral zaradi pravočasnih tehničnih (logističnih) priprav čim prej sprejeti odločitev, katera parlamentarna srečanja bo organiziral in kdaj, da so lahko strokovne službe državnega zbora pristopile k pripravam za njihovo izvedbo. Po potrebi in v skladu z nalogami so bile $v$ priprave in izvedbo projekta vključene vse službe državnega zbora, nekatere stalno, nekatere občasno. Koordinacijo priprav je vodil generalni sekretar prek projektne skupine za predsedovanje, ki je bila ustanovljena aprila 2006 z nalogo tehnične priprave in celotne logistične podpore izvedbe predsedovanja $\vee$ državnem zboru.

Pomembno je izpostaviti tudi zelo dobro sodelovanje in koordinacijo $s$ službami Vlade RS, s čimer je bila preprečeno morebitno podvajanje nalog in aktivnosti ter predvsem zmanjšanje nepotrebnih dodatnih stroškov (npr. prevozi, varovanje....).

Po temeljitem premisleku ter na podlagi pridobljenih informacij in nasvetih je bila na začetku priprav oblikovana posebna nova organizacijska shema 
Lovro Lončar

Organiziranost služb Državnega zbora Republike Slovenije -

izkušnje in novim izzivom naproti

vodenja in koordinacije projekta predsedovanja $v$ državnem zboru, ki je omogočila kakovostno in učinkovito izvedbo nalog $\vee$ zvezi s predsedovanjem.

Slika 3: Projektna organizacijska shema organiziranosti služb državnega zbora v času predsedovanja Svetu EU

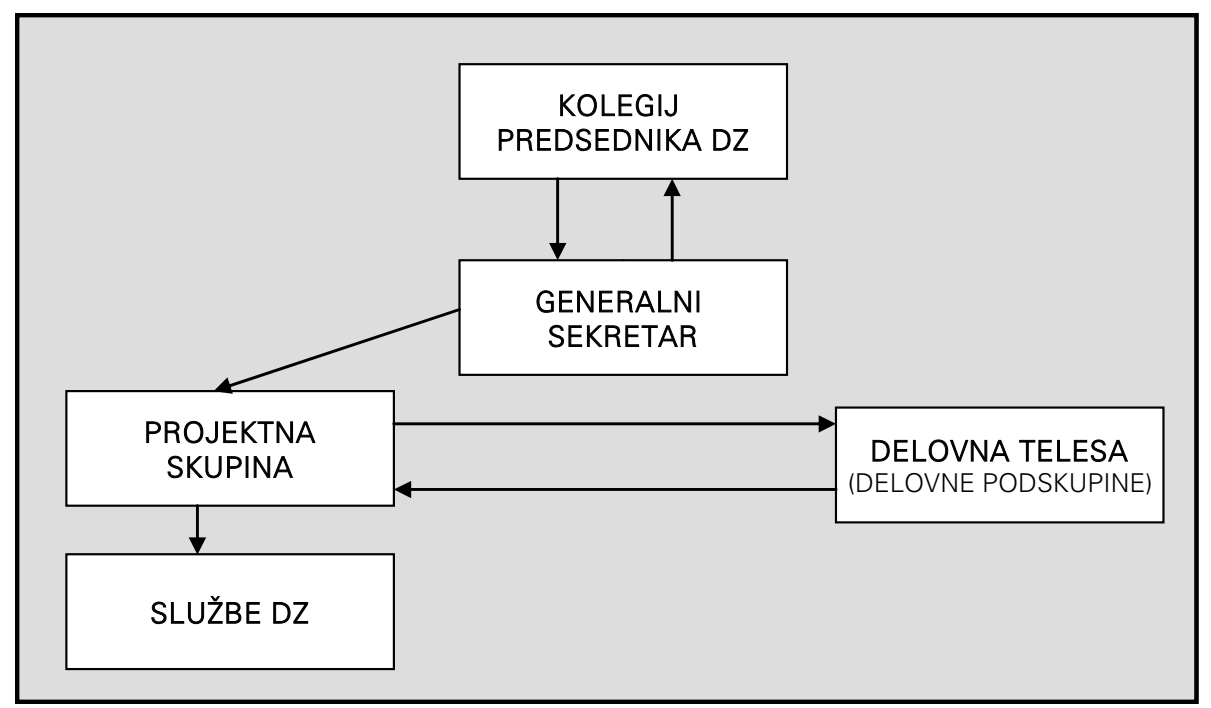

Vir: lastni

Službe državnega zbora so v času predsedovanja Svetu EU prispevale velik del k uspešnosti projekta, ki je vzorčen primer za organiziranost služb v prihodnje ob tovrstnih projektih $v$ državnem zboru. Ključna izkušnja temelji na majhnosti operativne projektne skupine z zadostnimi pooblastili za koordinacijo vseh služb v državnem zboru.

\section{Novi izzivi za službe državnega zbora}

Pred vodstvom in službami v državnem zboru je $v$ prihodnjem obdobju, tako kratkoročnem kot dolgoročnem, kar nekaj nalog, ki so vezane na izvajanje nalog iz pristojnosti, ki jih državnemu zboru nalaga ustava in zakonodaja. Predstavljamo le nekatere:

a) Obravnava zadev EU

Izkušnje od 1. maja 2004 dalje, ko smo postali polnopravni člani EU, kažejo, da bo na tem področju treba storiti še nekaj korakov naprej, predvsem 
pri jasni opredelitvi in razmejitvi delovnih postopkov oz. procesov $\vee$ državnem zboru in informacijski podpori, ki je za nacionalni zakonodajni postopek vzorno pripravljena in uporabna. Za uveljavitev teh procesov $v$ skladu $s$ poslovnikom bo potrebna odločna podpora poslank in poslancev, saj gre pri tem posredno za politične odločitve. Med službami ima odgovornost za pripravo in uveljavitev teh sprememb sekretariat državnega zbora.

Z vključitvijo Slovenije v EU je bilo namreč potrebno dokončno vzpostaviti novo kadrovsko in organizacijsko podporo delovanju državnega zbora pri obravnavi zadev EU, zagotoviti potrebno obravnavo gradiv $v$ slovenskem jeziku in zagotoviti celovito informacijsko podporo obravnavi gradiv EU.

Tako se tudi državni zbor ob vključitvi v EU, tako kot večina drugih negospodarskih in gospodarskih subjektov, ni mogel izogniti prilagajanju svoje organizacije in načinu dela sodobnim načinom poslovanja in evropskim trendom (družbenim, socialnim, ekonomskim in drugim), večji učinkovitosti, dostopnosti storitev državljanom, itd. EU je tudi za državni zbor postal neke vrste nov trg. Iz Bruslja, kjer imajo sedež glavne evropske institucije, prihajajo dokumenti, ki jih mora državni zbor $v$ luči našega sodelovanja v evropskih institucijah obravnavati $v$ skladu z zakonodajo in pristojnostmi in do njih zavzeti svoja stališča. Odziv na dokumente iz okolja mora biti hiter, pravilen (zakonit) in učinkovit. Pri prvi organizaciji teh procesov se je državni zbor zgledoval po organizaciji dela in služb $\checkmark$ parlamentih $z$ dolgotrajno evropsko parlamentarno tradicijo. Temu je moral in še mora nadalje prilagajati postopke obravnave zadev EU.

\section{b) Mednarodno sodelovanje}

Svoje bogate izkušnje in znanje službe lahko prenašajo tudi v okviru mednarodnih projektov prenašanja dobrih praks $v$ druge parlamente, kjer so uslužbenci državnega zbora predvsem zaželeni kot svetovalci $v$ državah na območju bivše Jugoslavije. Tovrstno sodelovanje je odlična promocija služb in njihovo angažiranje potrditev kakovosti in slovesa njihovega dela. Za tovrstno dejavnost državnega zbora je poleg vodstva pristojen in odgovoren za promocijo in uveljavitev predvsem oddelek za mednarodno sodelovanje, protokol in prevajanje $v$ okviru sekretariata državnega zbora.

Vpetost služb državnega zbora $\vee$ mednarodne parlamentarne in druge povezave je izjemnega pomena za krepitev vloge in položaja služb, predvsem zaradi medsebojne izmenjave informacij in izkušenj ter znanja med službami v različnih parlamentih. Izkušnje kažejo, da so težave služb pri izvajanju svojega poslanstva podobne ali primerljive med parlamenti, načini njihovega reševanja pa različni. Tudi organizacija služb se med seboj razlikuje. Ravno ta različnost pa 
Lovro Lončar

Organiziranost služb Državnega zbora Republike Slovenije izkušnje in novim izzivom naproti

bo omogočala, da na podlagi čim večjega in intenzivnega sodelovanja državni zbor pride do učinkovitih rešitev za prihodnje delo.

c) Spremembe poslovnika državnega zbora

S spremembami poslovnika bi lahko poenostavili nekatere postopke pri zakonodajnem postopku in pri pripravi in izvedbi sej državnega zbora, kot je npr. omejitev časa razprav poslank in poslancev, najava razpravljavcev...

Poslovnik ureja organizacijo in delo državnega zbora ter uresničevanje pravic in dolžnosti poslank in poslancev. Novi poslovnik državnega zbora je stopil v veljavo leta 2002 (Ur.list RS, št.35/02), ko je korenito spremenil način dela $\vee$ državnem zboru, predvsem na področju zakonodajnega postopka in organizacije sej državnega zbora in njegovih delovnih teles. Izkušnje pri delu v državnem zboru v letih po njegovi uveljavitvi so pokazale potrebo po nekaterih spremembah poslovnika. Del teh sprememb je bilo uveljavljenih že s spremembo poslovnika $\vee$ mandatnem obdobju 2004 - 2008 (Ur.list RS št.64/07, 92/07) Noveliran je bil način možnosti vlaganja amandmajev, jasno definiran postopek obravnave predlogov aktov $\vee$ enofaznem postopku itd. Nekatere rešitve pa žal niso bile sprejete, čeprav so bile službe mnenja, da bi bile za še bolj organizirano delo državnega zbora dobrodošle, predvsem pa bi odpravile nekatere dvome ob izvajanju poslovniških določil. Za morebitne spremembe bi moral sekretariat državnega zbora predhodno pridobiti ustrezno podporo poslank in poslancev, ki spremembe poslovnika sprejemajo z dvotretjinsko večino vseh navzočih poslank in poslancev.

d) Kakovost in učinkovitost

Stopnja kakovosti in učinkovitosti dela $v$ vsaki organizaciji je bistvenega pomena za delovanje neke organizacije. Želja in seveda tudi potreba po stalnem kakovostnem in učinkovitem delu je tudi v državnem zboru. Tako je tudi v državnem zboru aktualno razmišljanje o možnostih spremljanja (merjenja) učinkovitosti, ki posledično vodi $v$ še boljše rezultate dela in zadovoljstvo uporabnikov.

Na področju zagotavljanja večje učinkovitosti in približevanja uporabnikom $\checkmark$ državnem zboru je bilo storjenega že veliko. Tako je bil že leta 1995 ustanovljen Odbor za kakovost, ki je deloval približno leto in pol (Žagar,2006). Od predvidenih prihodnjih izzivov izstopa zlasti dejstvo, da je $\vee$ prihodnjih letih realno pričakovati merjenje dela zaposlenih $v$ državnem zboru. To bo predvidoma omogočeno na podlagi izsledkov raziskave o spremljanju kakovosti in učinkovitosti služb v državnem zboru, ki je potekala približno leto dni do oktobra 


\section{Organiziranost služb Državnega zbora Republike Slovenije -} izkušnje in novim izzivom naproti

2008. Raziskavo je opravila Ekonomska fakulteta Univerze v Ljubljani, njeni izsledki pa bodo $v$ državnem zboru predstavljeni predvidoma $\vee$ prihodnjih mesecih.

$Z$ omenjeno raziskavo bo torej dana podlaga za spremljanje učinkovitosti in kakovosti dela služb državnega zbora, z uporabo ustreznih mehanizmov, ki bodo omogočili kontinuirano izboljševanje učinkovitosti in kakovosti njihovega dela. Glede na primerjalne izkušnje kaže, da bo državni zbor (vsaj po razpoložljivih podatkih) med prvimi parlamenti, ki bo konkretno pristopil k sistematičnemu načinu spremljanja dviga kakovosti in učinkovitosti v praksi. Pri tem bodo morale sodelovati vse službe, nosilstvo aktivnosti pa bo moral prevzeti direktorat državnega zbora.

Ob tem bo pomembno ohraniti avtonomnost služb, hkrati pa zagotoviti njihove poenostavitve in pocenitve delovanja. Službe državnega zbora so razvejan sistem, tak sistem pa je lahko dostikrat zbirokratiziran in tog. Zato je bilo v preteklih letih sprejetih več internih aktov, ki so namenjeni bolj organiziranemu in učinkovitemu delu.

Večjo kakovost in učinkovitost dela bo mogoče doseči tudi z analizo vseh procesov $v$ državnem zboru, kjer bo treba ugotoviti trenutno stanje, potrebe in želje, predvsem pa poti za racionalizacijo in poenostavitev postopkov. Predvsem pa bi bilo treba na začetku vsakega mandata državnega zbora sprejeti strateški program dela služb, ki bi ga obravnaval tudi kolegij predsednika državnega zbora, ki vsako leto potrjuje finančni načrt državnega zbora pred dokončnim sprejemom na seji državnega zbora.

e) Informatizacija

Državni zbor je glede informacijske podpore zakonodajnemu delu državnega zbora med vodilnimi parlamenti $\vee$ EU, nov izziv pa predstavlja celotno eposlovanje, ki bo že prihodnje leto predvidoma nadgrajeno z elektronskim podpisom in popolno informatizacijo vhodne in izhodne pošte $v$ državnem zboru, kar bo ena izmed ključnih nalog informacijskega sektorja. Sodobna informacijska podpora $v$ državnem zboru je stalen cilj, tako za interno delo kot za komunikacijo z okoljem. Za dobro delovanje služb je potrebna zanesljiva informacijska podpora, ki pomeni predvsem racionalizacijo postopkov in posledično racionalizacijo materialnih stroškov z vidika proračunskih sredstev, lahko pa tudi spodbuja k inovativnosti in predlogom boljšega dela.

\section{f) Obveščanje javnosti}

Za obveščanje javnosti je $v$ državnem zboru pristojna in odgovorna služba za odnose z javnostmi, ki pri tem intenzivno sodeluje z vsemi službami 
Lovro Lončar

Organiziranost služb Državnega zbora Republike Slovenije izkušnje in novim izzivom naproti

državnega zbora. Državni zbor o svojem delu obvešča javnost prek glasila Poročevalec, v katerem so objavljena vsa gradiva, vsi sklepi državnega zbora, sprejeti ob obravnavi posameznih zadev, poročila in mnenja delovnih teles. Do leta 2007 je glasilo izhajalo le v tiskani obliki, sedaj pa izhaja v elektronski obliki, za potrebe poslank in poslancev tudi $\vee$ tiskani obliki. $S$ spremembo poslovnika je dana formalna podlaga, da lahko $v$ prihodnje izhaja le $v$ elektronski obliki, kar naj bi se po predvidevanjih uveljavilo $v$ naslednjem letu.

Velik prispevek k obveščanju javnosti predstavljajo tudi neposredni prenosi sej državnega zbora in njegovih delovnih teles, tako prek spletnih strani državnega zbora (te so bile obnovljene oz. posodobljene $v$ letu 2006) kot prek TV kanala nacionalne televizije. $\vee$ zvezi s tem bo treba še večjo pozornost nameniti večjemu reklamiranju t. i. parlamentarnega TV kanala in proučiti možnost stalnih prenosov tudi prek radijskih kanalov.

$\checkmark$ povezavi z Zavodom za turizem Mestne občine Ljubljane bi lahko večjo pozornost namenili organiziranim obiskom v državnem zboru. Število obiskov v državnem zboru je v letu 2007 naraslo za 25\%, tako da državni zbor beleži obisk preko 40000 obiskovalcev letno. Pri tem je pomembna predvsem izobraževalna funkcija ogledov poslopja državnega zbora, saj imajo obiskovalci možnost vpogleda $v$ zgodovino slovenskega parlamentarizma in $\vee$ delo državnega zbora $\vee$ sedanjem času.

\section{g) Vloga služb pri izvajanju storitev}

Tudi v državnem zboru bo treba, še posebej v okviru direktorata, tako kot drugje $\vee$ javni upravi, analizirati morebitno oddajo del oz. storitev zunanjim izvajalcem. To se $\vee$ nekaterih segmentih že dogaja (npr.: delno varovanje, vzdrževanje objekta, urejanje okolice objekta...), seveda na podlagi ustreznih analiz in študij. Vsi ti koraki morebitne oddaje del zunanjim izvajalcem morajo biti načrtni in premišljeni, podprti ne le z ekonomsko študijo, ampak tudi vsemi drugimi možnimi vplivi na tovrstno odločitev.

\section{h) Upravljanje s človeškimi viri}

Vodstvo državnega zbora se skupaj z oddelkom za organizacijo in kadre trudi čim večjo pozornost nameniti kadrovskim vprašanjem. $V$ preteklosti se je vsepovsod $v$ javni upravi preveč ukvarjalo $z$ evidencami in premalo $s$ kadri. Zaradi obilice dela in zastavljenih projektov pa je nevarnost, da se ta cilj ne izvaja oz. ne uresničuje. Posledice se lahko nezadovoljstvo in slab odnos do dela. Zadovoljstvo zaposlenih pa je neposredno povezano s kakovostjo in z učinkovitostjo dela. 


\section{Organiziranost služb Državnega zbora Republike Slovenije -} izkušnje in novim izzivom naproti

Kadri so ključni element vsake organizacije za doseganje ciljev oz. njenega poslanstva. Pri vodenju ne smemo misliti le na procese, ki izhajajo iz zakonodaje in za zakonodajo in na rezultate teh procesov; ne smemo namreč pozabiti na ljudi, ki so aktivno vključeni $v$ te procese. Vsaka sprememba, ki vpliva na status ali položaj uslužbencev, je lahko občutljiva in vpliva na organizacijsko kulturo, vedenje in odnose $v$ organizaciji. Za vodenje je torej poleg strokovnega znanja potrebno ogromno veščin za delo z ljudmi ter vse več konceptualnega znanja za reševanje vprašanj in pravilno odločanje.

Za izvajanje vseh nalog z obstoječimi kadrovskimi resursi so vodjem med drugim na voljo predvsem naslednji ukrepi:

- oblikovanje projektne oz. delovne skupine za čas trajanja projekta;

- premeščanja uslužbencev in njihovega dela na projektno organiziranih nalogah in drugih oblikah neformalne organizacije, ki omogočajo, da zaposleni vstopajo na številne načine v proces dela, prevzemajo naloge in odgovornosti za daljši ali krajši čas;

- načrtno in usmerjeno izobraževanje, usposabljanje in izpopolnjevanje uslužbencev, da bi prispevali k boljšemu delu organa, uprave in hkrati $\mathrm{k}$ delovnemu in osebnemu razvoju uslužbencev.

Največji izziv na področju upravljanja s človeškimi viri v državnem zboru bo $\checkmark$ prihodnjem obdobju morebitni "projekt zagotavljanja enakomerne obremenitve uslužbencev v Državnem zboru". Dejstvo je, da so nekateri uslužbenci preobremenjeni, nekateri pa so premalo obremenjeni. Kljub nekaterim dosedanjim poizkusom pravičnejše, enakomernejše porazdelitve delovnih nalog večjih rezultatov $v$ tej smeri ni bilo, tudi iz razloga, da bi bil za to potreben t. i. politični konsenz poslank in poslancev, ki bi za izvedbo le-tega morali sprejeti ustrezne odločitve (sprememba odloka in soglasje k spremembam pravilnika), ki bi omogočile delno reorganizacijo služb.

Ob tem pa bo treba zagotoviti čim večjo stalnost zaposlenih v državnem zboru in zagotoviti motivacijski faktor, da bodo uslužbenci ostajali zaposleni v državnem zboru. Oddelek za organizacijo in kadre bo treba kadrovsko okrepiti in z dosledno delitvijo nalog zagotoviti, da bo oddelek kot celota lahko uspešno zagotavljal izvedbo vseh nalog kadrovske funkcije.

Pomembno področje predstavlja tudi izobraževanje. Še večjo pozornost bo treba zagotoviti pogojem za strokovno izobraževanje doma in $v$ tujini, funkcionalno izobraževanje, izobraževanje za osebnostni razvoj (tudi veščine vodenja in 
Lovro Lončar

Organiziranost služb Državnega zbora Republike Slovenije izkušnje in novim izzivom naproti

upravljanja), izobraževanje za pridobitev strokovne izobrazbe. Predvsem pa bo treba zagotoviti izobraževanje za vse uslužbence (tudi z obvezno napotitvijo), saj se nekateri izobraževanja ne udeležijo. Izobraževanje javnega uslužbenca je namreč ne le pravica, ampak tudi dolžnost. Pri tem pa je treba pravočasno in plansko ugotoviti potrebe po izobraževanju zaposlenih, zagotoviti potrebne organizacijske naloge $v$ zvezi z izobraževanjem javnih uslužbencev in pripraviti letni program za izobraževanje in izpopolnjevanje zaposlenih.

\section{Zaključek}

Državni zbor je velika organizacija, ki se mora tako kot podjetje na trgu stalno prilagajati spremembam in novim izzivom, ki jih prinaša napredek sodobne družbe. Državni zbor je ob tem $\vee$ skladu s predpisi podrejen vsem zakonitostim sodobnega vodenja in poslovanja $\vee$ javni upravi $s$ ciljem preglednosti in učinkovitosti poslovanja. Rezultate dela služb ocenjujejo poslanke in poslanci, poslansko delo pa ocenjuje javnost.

Tem ciljem službe državnega zbora tudi sledijo. Seveda bi bilo mogoče (in tudi nujno) nekatere postopke in organizacijo ter vodenje $\vee$ prihodnje še izboljšati, vendar je zato potreben čas in čim širše soglasje tistih, ki o tem odločajo. Nadaljnje uspešno preoblikovanje, modernizacija in prilaganje služb državnega zbora zahtevam iz okolja pa je mogoče le ob reševanju vprašanj, povezanih s človeškimi viri. Le usposobljeni kadri so zmožni sprejeti uvajanje novih tehnologij in postopkov dela $\vee$ upravi. Ob tem bo treba zagotavljati stalno spremljanje kakovosti in učinkovitosti v službah državnega zbora in skrbeti za njuno nadgradnjo. 


\title{
Organiziranost služb Državnega zbora Republike Slovenije -
} izkušnje in novim izzivom naproti

\begin{abstract}
Mag. Lovro Lončar je bil v oktobru leta 2004 imenovan za generalnega sekretarja Državnega zbora Republike Slovenije. To funkcijo je opravljal do konca mandata leta 2008. Leta 1991 je diplomiral na Višji upravni šoli Univerze v Ljubljani, leta 1998 je diplomiral na Fakulteti za organizacijske vede, Kranj, Univerze v Mariboru. Na tej fakulteti je leta 2004 tudi magistriral - smer splošni kadrovski management. Vseskozi od leta 1992 dalje je zaposlen v javnem sektorju (v lokalni skupnosti, javnem zavodu, ministrstvu, državnem zboru). Njegovo delovno in strokovno delo sega predvsem na področje organizacije dela, javne uprave in kadrovskega menedžmenta. S tega področja je avtor nekaj objavljenih člankov, občasno sodeluje s prispevki na konferencah in strokovnih srečanjih, kot zunanji ekspert je sodeloval $v$ pedagoškem procesu na fakulteti.
\end{abstract}

\section{Literatura in viri}

- Ustava RS (Ur. list RS, št. 33/91, 42/97, 66/00, 23/03, 69/04, 68/06)

- Zakon o poslancih (Ur. list RS, št. 24/05 - uradno prečiščeno besedilo)

- Zakon o javnih uslužbencih (Ur. list RS, št. 32/06 - uradno prečiščeno besedilo, 33/06, $63 / 07,65 / 08,69 / 08)$

- Zakon o sistemu plač v javnem sektorju (Ur. list RS, 14/06 - uradno prečiščeno besedilo, 57/07, 95/07, 110/07,17/08, 58/08, 69/08, 69/08, 80/08)

- Odlok o notranji organizaciji, delovnih mestih in nazivih v službah DZ (Ur.list RS, št. 50/04, 32/08)

- $\quad$ Poslovnik DZ RS (Ur. list RS, št. 35/02, 60/04, 64/07, 92/07)

- Pravilnik o notranji organizaciji in sistemizaciji delovnih mest v službah DZ (štev: 04003/89-1/56 z dne 01.07.2004, 25.11.2004, 28.01.2005, 11.04.2005, 01.04.2006, 15.11.2006, 09.03.2007, 06.06.2007, 15.01.2008, 23.01.2008, 29.07.2008)

- Državni zbor RS (2004): Poročilo o delu Državnega zbora v mandatnem obdobju 20002004; Državni zbor RS, Ljubljana.

- $\quad$ Državni zbor RS (2008): Kadrovsko poročilo DZ za obdobje 2004-2008 ;Oddelek za organizacijo in kadre, Ljubljana.

- $\quad$ Državni zbor RS :Gradiva projektne skupine Državnega zbora za predsedovanje, namenjeno kolegiju predsednika Državnega zbora RS (informacije o pripravah na predsedovanje EU) - kolegiji, sklicani za dne 12.05.2006, 14.07.2006, 13.04.2007, 20.04.2007, 13.07.2007, Ljubljana.

- Lončar, L.(2004): Kadrovski management in reforma javne uprave; magistrsko delo, Fakulteta za organizacijske vede Univerze v Mariboru, Kranj.

- Žagar, K.(2006): Spremljanje kakovosti in učinkovitosti v Državnem zboru, Državni zbor, naloga Raziskovalnega oddelka št. 20/2006, Ljubljana.

- $\quad$ Državni zbor RS (2008), http://www.dz-rs.si 
Lovro Lončar

Organiziranost služb Državnega zbora Republike Slovenije izkušnje in novim izzivom naproti

SUMMARY

\section{ORGANISATION OF THE SERVICES OF THE NATIONAL ASSEMBLY - EXPERIENCE AND FUTURE CHALLENGES}

The services of the National Assembly of the Republic of Slovenia carry out expert, administrative, technical and other tasks, thus providing the conditions for the work of the National Assembly. The National Assembly is the highest legislative and representative body in Slovenia, which makes the mission of its services particularly important and responsible, although it often goes unnoticed by the general public. However, without the support of the services, the deputies would lack the necessary conditions for their work. Moreover, it is important that the services adjust to the modern trends in administration, while at the same time maintaining the traditional functions and status held by the services in parliaments with yearlong parliamentary democracy experience, such as professionalism, qualification and, above all, political independence. As for the future, there are several challenges facing the services of the National Assembly in the coming years.

According to the Slovenian Constitution, the National Assembly is the highest representative and legislative body in the country. It is composed of 90 deputies elected by direct democratic elections for a period of four years. The deputies discuss and adopt laws and other acts and have a control and an electoral function. They carry out their functions in different working bodies (in the 2004-2008 term, 26 working bodies - committees and commissions - were established) as well as at plenary sessions.

The administrative management of the National Assembly is tasked with the organisation and management of the National Assembly's expert services that indirectly, from the "backstage", provide for a smooth running of the legislative procedure - the main procedure taking place in the National Assembly. The administrative management is not directly involved in the decision-making and is thus excluded from politics which, of course, has the final say in the National Assembly - the house of democracy.

The National Assembly employs functionaries - i.e. politicians (directly elected deputies) and their staff who are civil servants recruited by the deputy groups for the time of existence of the latter - as well as civil servants regularly employed in the National Assembly's expert services. 
The services of the National Assembly are headed by the Secretary General who is the only functionary in the National Assembly besides the deputies. The Secretary General might as well be called an "administrative functionary" as he carries out technical rather than political tasks. The Secretary General organises and coordinates the services which work and carry out tasks for the National Assembly, its working bodies, the deputy groups and the deputies; provides for a coordinated operation of the services; promotes the development of the organisation and work; and performs other tasks in accordance with the National Assembly's Rules of Procedure and other regulations.

The main task of the administrative management in the National Assembly is to provide that the legislative procedure runs smoothly and in accordance with the law, and that also the operations and the development of the National Assembly's services run smoothly.

The interaction of both the above tasks is essential. In coordinating the services, constitutionality and legality of work needs to be ensured, as well as the openness of work of the National Assembly.

The management of the National Assembly must also ensure a constant flexibility of its services in terms of organisation, human resources, and contents, considering the powers and tasks of the services. In organising their work, the services must sometimes even adapt to the adopted political decisions. If, for example, a decision on establishing a new working body is adopted, the services need to provide such with all the necessary expert assistance (system of positions, new recruitment, offices, other material conditions, etc.). Constant changes in the system of positions - with due consideration of legal restrictions, of course - are a normal and occurring phenomenon, although most frequently internal resources are sought, i.e. by transferral of staff. In terms of human resources, the National Assembly thus aims at maximum interdisciplinarity.

The organisational chart of the National Assembly reveals a considerable diversification of its services. The National Assembly's autonomy and independence in terms of its legislative power are also shown in the structure of its services, whereby the objectives pursued are rationality and use of available resources, thus providing for a full and independent support to the National Assembly by its services, including technical, translation, IT, catering, printing, security, transport, cleaning, reception, protocol, library, research, documentation, and other services. Thus, the 
Lovro Lončar

Organiziranost služb Državnega zbora Republike Slovenije izkušnje in novim izzivom naproti

services carry out all the key tasks of an organisation: technical, finance and accounting, security, administrative and consultative, etc.

Coordination of activities and tasks as well as fast flow of information are of paramount importance for the management of the mentioned services. They are achieved by contemporary means of communication and through project work, requiring - in addition to expert knowledge and experience - compromises, based on expert opinion and legal basis. To this end, relevant internal acts have been adopted, providing that in order to be able to effectively and efficiently perform their tasks, internal organisational units as well as individual civil servants need to engage in cooperation, including coordination of work programmes, exchange of opinions, experience, information and communications, and participation in working groups (as stipulated in the Rules on Internal Organisation and the System of Positions in the Services of the National Assembly). In particular, the work of the National Assembly is subject to time limits, provided under different regulations (also the Constitution). In order to guarantee that these limits are met during discussions of individual matters, the services of the $\mathrm{Na}$ tional Assembly need to provide for the actuality of the information and data supplied. A prompt response by the National Assembly to the input, i.e. draft laws and other acts submitted to discussion, is indispensable to provide that e.g. no unconstitutional situation is created due to possible failure to comply with time limits - much the same as in business life where an untimely response to market requirements might influence the operations and liquidity of a business entity. However, it needs to be added that the response of the National Assembly does not depend solely on its services, but on political decisions of the deputies as well.

In the future, both the short-term and the long-term, the management and the services of the National Assembly will be dealing with quite a number of tasks pertaining to those provided by the Constitution and laws. In this context, I would like to highlight the following:

- discussion of EU matters,

- international cooperation,

- amendments to the Rules of Procedure of the National Assembly,

- quality and efficiency,

- informatisation,

- public relations,

- role of the NA services in the provision of services, 
- human resources management.

The National Assembly is a comprehensive organisation. Much like a business entity serving on the market, it has to continually adapt to changes and challenges posed by the progress of the modern society. In doing so and according to the regulations, the National Assembly is subject to all principles governing the contemporary civil services management and its operations with the aim of ensuring transparency and operational efficiency. The results of its work are assessed by the deputies, whose own work is, in turn, valuated by the public.

Characteristic for the work of an administrative manager is that he has to anticipate the changes. To be able to do so, the manager must have received appropriate training and education. Further requirements include an established system of responsibilities as well as clearly defined goals which need to be achieved.

The services of the National Assembly follow these goals. The need to improve some processes, the organisation and the management is indeed present, but it requires time and a broad consensus of those competent for adopting decisions. Successful further reorganisation, modernisation and adaptation of the services of the National Assembly to the requirements posed by the society are only possible when accompanied by a process for solving the issues related to human resources. Only trained staff is capable of adapting to new technologies and administrative work procedures.

Due to the complexity of work, all organisational measures need to be planned and carefully considered in order not to cause delays in the accomplishment of the mission the National Assembly. This is the responsibility of all members of the "top administrative management" employed by the services of the National Assembly. The organisation and management of these services are continuous processes, which need to be constantly monitored and enhanced in order to guarantee that the fundamental principles of contemporary administration are observed: legality, objectivity, expertise, political neutrality, user-orientation, transparency, effectiveness, efficiency and economy of operations. 
